\title{
Insulin-like Receptor and Insulin-like Peptide Are Localized at Neuromuscular Junctions in Drosophila
}

\author{
Michael Gorczyca, Carolyn Augart, and Vivian Budnik \\ Department of Biology, Neuroscience and Behavior Program, University of Massachusetts, Amherst, Massachusetts \\ 01003
}

Insulin and insulin-like growth factor (IGF) receptors are members of the tyrosine kinase family of receptors, and are thought to play an important role in the development and differentiation of neurons. Here we report the presence of an insulin-like peptide and an insulin receptor (dinsR) at the body wall neuromuscular junction of developing Drosophila larvae. dInsR-like immunoreactivity was found in all body wall muscles at the motor nerve branching regions, where it surrounded synaptic boutons. The identity of this immunoreactivity as a dinsR was confirmed by two additional schemes, in vivo binding of labeled insulin and immunolocalization of phosphotyrosine. Both methods produced staining patterns markedly similar to dinsR-like immunoreactivity. The presence of a dinsR in whole larvae was also shown by receptor binding assays. This receptor was more specific for insulin ( $>25$-fold) than for IGF II, and did not appear to bind IGF I.

Among the $\mathbf{3 0}$ muscle fibers per hemisegment, insulin-like immunoreactivity was found only on one fiber, and was localized to a subset of morphologically distinct synaptic boutons. Staining in the CNS was limited to several cell bodies in the brain lobes and in a segmental pattern throughout most of the abdominal ganglia, as well as in varicosities along the neuropil areas of the ventral ganglion and brain lobes. Insulin-like peptide and dinsR were first detected by early larval development, well after neuromuscular transmission begins. The developmental significance of an insulin-like peptide and its receptor at the neuromuscular junction is discussed.

[Key words: growth factor, in vivo receptor binding, motorneuron, neuropeptide, tyrosine kinase, synaptic boutons]

The mechanisms involved in the process of growth cone pathfinding, synaptogenesis, and synaptic maturation are incompletely understood. Some of the factors proposed to be involved in these processes include cell recognition and cell adhesion molecules, neurotransmitters and their receptors, neuronal ac-

Received Oct. 20, 1992; revised Feb. 3, 1993; accepted Feb. 10, 1993.

We thank Drs. E. Connor, R. Murphey, L. Schwartz, C. F. Wu, and G. Wyse for helpful comments on the manuscript. We are grateful to Drs. A. Simon and E. Bittman for use of their facilities in receptor binding assays and to L. Schwartz for use of his computer equipment and for initially providing us with anti-phosphotyrosine antibody. We also express thanks to the reviewers for their insightful critiques of the manuscript. This work was supported by NIH Grant NS3007201 and by an Alfred P. Sloan fellowship to V.B.

Correspondence should be addressed to Dr. Michael Gorczyca, Department of Biology, Morrill Science Center, University of Massachusetts, Amherst, MA 01003. Copyright (C) 1993 Society for Neuroscience $0270-6474 / 93 / 133692-13 \$ 05.00 / 0$ tivity, calcium concentration, and neurotrophic factors (Hubel et al., 1977; Haydon et al., 1984; Budnik et al., 1989; Schmidt and Tieman, 1989; Kater and Mills, 1991; Goodman et al., 1992). A molecule that may be involved in the development and maturation of neurons is insulin (reviewed in Unger et al., 1991). During the past two decades a wealth of evidence has accumulated showing that insulin, insulin-like growth factors (IGF), and their receptors are present and synthesized in the nervous system of both vertebrates (reviewed in Unger et al., 1991) and invertebrates (Duve and Thorpe, 1979; Garofalo and Rosen, 1988; Hansen et al., 1990; Van Heumen and Roubos, 1990). One current view of insulin and IGF's role is that of neurotrophic factors (Ishii, 1989; reviewed in Unger et al., 1991). This putative developmental function is supported by the observation that in both vertebrates and invertebrates, insulin and IGF enhance neurite elongation, synaptic maturation, and neuronal survival in vitro (Puro and Agardh, 1984; Recio-Pinto et al., 1986; Mudd et al., 1988; Kits et al., 1990; Vanhems et al., 1990). Recently, it has been shown that IGF II gene expression is correlated with synaptogenesis and synapse elimination at the vertebrate neuromuscular junction (Ishii, 1989), and that exposure of innervated muscle to IGFs leads to nerve sprouting (Caroni and Grandes, 1990).

Both insulin receptors (InsR) and IGF receptors are members of the tyrosine kinase family of growth factor receptors (reviewed in Ullrich, 1985; Unger et al., 1991). Interestingly, several observations have implicated tyrosine kinases in the development of neural tissues (reviewed in Schlessinger and Ullrich, 1992). In vertebrates, the tyrosine kinase encoded by $c$-src is expressed in differentiating retina and cerebellum, as well as in growth cones (Sorge et al., 1984; Brugge et al., 1985; Fults et al., 1985; Maness et al., 1988). In Drosophila, the Abelson tyrosine kinase is involved in axonogenesis and pathfinding through interactions with genes such as disabled and fasciclin I (Gertler et al., 1989; Elkins et al., 1990). In addition, the tyrosine kinase encoded by sevenless is required for determination of cell fate in the Drosophila eye (Basler et al., 1991).

The fruit fly Drosophila melanogaster is an attractive in vivo system to study the role of insulins and their receptors in the nervous system. Alterations in their structure and levels of expression can be brought about by using molecular and genetic techniques. In fruit flies, an InsR homolog (dInsR) has been cloned and shown by in situ hybridization to be expressed at high concentration in the nervous system (Nishida et al., 1986; Petruzzelli et al., 1986; Garofalo and Rosen, 1988). Like the mammalian InsR, the Drosophila homolog is a glycoprotein composed of two $\alpha$ - and two $\beta$-subunits (Fernandez-Almonacid and Rosen, 1987). In addition, dInsR can include a fifth subunit 
not present in the vertebrate counterpart (Fernandez-Almonacid and Rosen, 1987). The $\alpha$-subunits are extracellular and contain the insulin-binding domains. Each $\beta$-subunit consists of a transmembrane and a cytoplasmic domain, the latter of which contains an insulin-dependent tyrosine kinase (Petruzzelli et al., 1985a,b, 1986). This tyrosine kinase has high homology with the vertebrate InsR kinase domain and with the Abelson tyrosine kinase (Petruzzelli et al., 1986).

An insulin-like peptide with biological activity similar to insulin, and with the same molecular weight as insulin, has been isolated from Drosophila. However, its specific amino acid sequence is not known (Seecof and Dewhurst, 1974; Meneses and De los Angeles Ortíz, 1975; Le Roith et al., 1981). As in several other vertebrates and invertebrates, insulin promotes neuronal differentiation and neurite elongation of embryonic Drosophila neurons in culture (Seecof and Dewhurst, 1974; O’Dowd, 1990).

In this article we determine the localization of a dInsR and an insulin-like peptide in the body wall neuromuscular junction, as well as their temporal expression. We show that a dInsR is concentrated at neuromuscular junctions near the nerve branching areas of all muscle fibers. An insulin-like peptide is also expressed at presynaptic terminals of body wall muscles. In contrast to the dInsR, however, this peptide is expressed at synaptic boutons of a single muscle fiber per hemisegment. Both dInsR and insulin-like peptide appear at similar stages of larval neuromuscular junction development. The temporal and spatial restriction of $\mathrm{dIns} R$ and insulin-like peptide to the developing neuromuscular junction suggests that they might be involved in the expansion and maturation of motor innervation during larval growth.

\section{Materials and Methods}

\section{Flies}

For these studies, the wild-type strain Canton-S was reared at $25^{\circ} \mathrm{C}$ in standard Drosophila medium.

\section{Immunocytochemistry}

A total of 309 larvae were dissected in $\mathrm{Ca}^{2+}$-free Drosophila saline and processed for immunocytochemistry according to Budnik et al., 1990 (except as noted below). Fluorescent samples were mounted in $1 \%$ phenylenediamine in $80 \%$ glycerol, $20 \mathrm{~mm}$ carbonate buffer, $\mathrm{pH} 9.0$. AntiHRP and anti-SSB (small synaptic bouton antigen) immunocytochemistry was performed according to Budnik and Gorczyca (1992). Samples were observed under epifluorescence on a Nikon microscope attached to a Bio-Rad M600 confocal unit. All photomicrographs were taken from abdominal segments $2-5$ and were processed using the NIH program IMAGE (version 1.4). No differences in staining were observed between these segments for all histochemical methods described in this article. Confocal images were photographed directly from the screen of a Macintosh black-and-white video monitor using Kodak T-max 100 film.

Insulin immunocytochemistry. To visualize insulin-like immunoreactivity, samples were immersed in Bouin's fixative $[75 \mathrm{ml}$ of saturated aqueous picric acid, $25 \mathrm{ml}$ of formalin (37\%; Fisher), $5 \mathrm{ml}$ of glacial acetic acid]. All washes were done using $0.1 \mathrm{~m}$ phosphate buffer, $\mathrm{pH}$ $7.2,0.2 \%$ Triton $\mathrm{X}-100$ (PBT). Three guinea pig anti-bovine/porcine insulin polyclonals (INCSTAR, Sigma, and ICN) were used at a 1:50, $1: 100$, and 1:400 dilution, respectively. Goat anti-guinea pig fluorescein isothiocyanate (FITC)-conjugated secondary antibody $(1: 120-1: 160$ dilution) was used. For preabsorption experiments anti-insulin antibodies were preabsorbed in $2.5 \times 10^{-6} \mathrm{M}$ porcine insulin (Sigma), human IGF I (Amersham), and human IGF II (Sigma) in PBT at room temperature for $24 \mathrm{hr}$ and centrifuged at $1900 \times \mathrm{g}$, and the supernatant was applied to the tissue sample.

dInsR-like immunocytochemistry. dInsR-like immunoreactivity was visualized using two mouse monoclonal antibodies against the $\alpha$-subunit of human placental InsR (Amhersham and Chemicon) at a 1:10 dilution.
Samples were fixed for 2-3 $\mathrm{hr}$ in freshly prepared $4 \%$ paraformaldehyde in $0.1 \mathrm{M}$ phosphate buffer, $\mathrm{pH} 7.2(\mathrm{~PB})$. All washes and dilution of antibodies were done in PB. Triton X-100 was not used as its presence significantly decreased immunoreactivity. FITC-conjugated sheep antimouse immunoglobulin (Boehringer Manheim) (1:50 dilution) was used as secondary antibody. In some experiments signal was intensified by using an anti-mouse biotinylated secondary (Vector) at a dilution of 1:20. FITC-conjugated avidin was reacted with the secondary for $2 \mathrm{hr}$ at 1:50 in PB.

Phosphotyrosine-like immunoreactivity. Phosphotyrosine-like immunoreactivity was visualized using a mouse monoclonal antibody that binds phosphorylated tyrosine residues with high specificity (ICN, clone PY20). This antibody was used at 1:50 dilution in PBT. Samples were processed as for dInsR-like immunofluorescence.

\section{Developmental analysis of dInsR and insulin-like immunoreactivity}

Egg laying occurred at $25^{\circ} \mathrm{C}$ for $2 \mathrm{hr}$ in fly cages that contained petri plates with sucrose-agar and a drop of live yeast paste, or enriched medium (Budnik et al., 1989). Larvae were staged based on developmental time, morphology of mouth hooks and spiracles, and size (Campos-Ortega and Hartenstein, 1985). Early first instar larvae were used within $15 \mathrm{~min}$ of hatching. Other first instar larvae were chosen between 12 and $22 \mathrm{hr}$ posthatching. Second instar larvae were collected from 0 to $18 \mathrm{hr}$ after the first to second instar molt. Early third instar larvae were chosen within $12 \mathrm{hr}$ of the second to third instar molt. Third instar larvae were collected while wandering on the walls of the tubes or cages.

For quantitative analysis of the number of boutons at each terminal, larvae from the above stages were stained using anti-HRP (Budnik et al., 1990), anti-SSB (Budnik and Gorczyca, 1992), and anti-insulin immunocytochemistry, using rhodamine- and/or FITC-conjugated secondary antibodies. The number of boutons at the third abdominal segment was counted directly on the fluorescent scope at $630 \times$ or $1000 \times$ magnification. We found that many more boutons could be distinctly observed by using immunofluorescence than by employing an HRP. conjugated secondary and drawing the terminals by camera lucida. Therefore, the number of boutons determined here is higher than the counts previously reported (Budnik et al., 1990). HRP-and SSB-positive boutons were counted in double-labeled preparations.

\section{In vivo insulin binding}

Larvae were incubated with normal $(1.8 \mathrm{~mm})$ or low-calcium $(0.1 \mathrm{~mm})$ saline in the presence of 10-100 nM bovine FITC-conjugated insulin (Sigma) for 3-5 hr at $4^{\circ} \mathrm{C}$. Samples were washed once with saline and fixed for $10 \mathrm{~min}$ with $4 \%$ paraformaldehyde, and then fixed again with Bouin's for $10 \mathrm{~min}$. Subsequently, specimens were washed and mounted as for immunofluorescence. Samples were observed under epifluorescent or confocal microscopy. In some experiments, samples were observed in vivo, before fixation.

\section{Isolation of an insulin-binding membrane fraction}

The insulin receptor was partially purified by the method of Petruzzelli et al. (1985a). Third instar larvae were collected, washed, and frozen at $-80^{\circ} \mathrm{C}$ until use (within $1-4$ weeks). All subsequent steps were carried out at $4^{\circ} \mathrm{C}$. In a typical experiment, approximately $40 \mathrm{gm}$ of larvae was homogenized in $100 \mathrm{ml}$ of isolation buffer ( $50 \mathrm{~mm}$ HEPES buffer, $\mathrm{pH}$ 7.8, $200 \mathrm{~mm}$ sucrose, $25 \mathrm{~mm}$ benzamidine, 2 mм EDTA, 1 mM EGTA, $10 \mu \mathrm{g} / \mathrm{ml}$ soybean trypsin inhibitor, $10 \mu \mathrm{g} / \mathrm{ml}$ aprotinin, $10 \mu \mathrm{g} / \mathrm{ml} \mathrm{leu}-$ peptin, $10 \mu \mathrm{g} / \mathrm{ml}$ pepstatin, and $1 \mathrm{~mm}$ phenylmethylsulfonyl fiuoride) using a Tissumizer blender (Techmar, two $10 \mathrm{sec}$ pulses at maximum setting) followed by homogenization in a glass-Teflon homogenizer. The homogenate was centrifuged at $1900 \times g$ for $10 \mathrm{~min}$, and the supernatant was filtered through a nylon mesh and saved. The pellet was resuspended in $100 \mathrm{ml}$ of isolation buffer, and the above procedure was repeated. The supernatants were combined and centrifuged at $40,000 \times g$ for 45 min to isolate the membrane fraction. The pellet was resuspended in $80 \mathrm{ml}$ of isolation buffer containing $2 \%$ Triton X-100 and gently stirred for $1 \mathrm{hr}$ to extract the receptor from the membranes. The suspension was then centrifuged at $40,000 \times g$ for $45 \mathrm{~min}$ to separate membranes from solubilized membrane proteins. The supernatant was applied to a 5-ml-WGA-agarose (Vector) column to affinity purify the dInsR. This column was previously washed with $100 \mathrm{ml}$ of buffer A (50 mM HEPES buffer, $\mathrm{pH} 7.6,150 \mathrm{~mm} \mathrm{NaCl}, 0.1 \%$ Triton X-100, $0.01 \%$ SDS), 100 
Figure 1. Confocal photomicrography of dInsR-like immunoreactivity at the body wall muscles. $A$, Area of muscle 12 and 13 near their motor nerve branch point, showing strong dInsR-like immunoreactivity at some synaptic boutons. Arrows point to the nerves. $B$, High-magnification view of one such bouton. $C$, Different section $1 \mu \mathrm{m}$ below that of $B$ showing the absence of immunoreactivity inside the bouton. Scale bar: $34 \mu \mathrm{m}$ for $A, 7 \mu \mathrm{m}$ for $B$ and $C$.
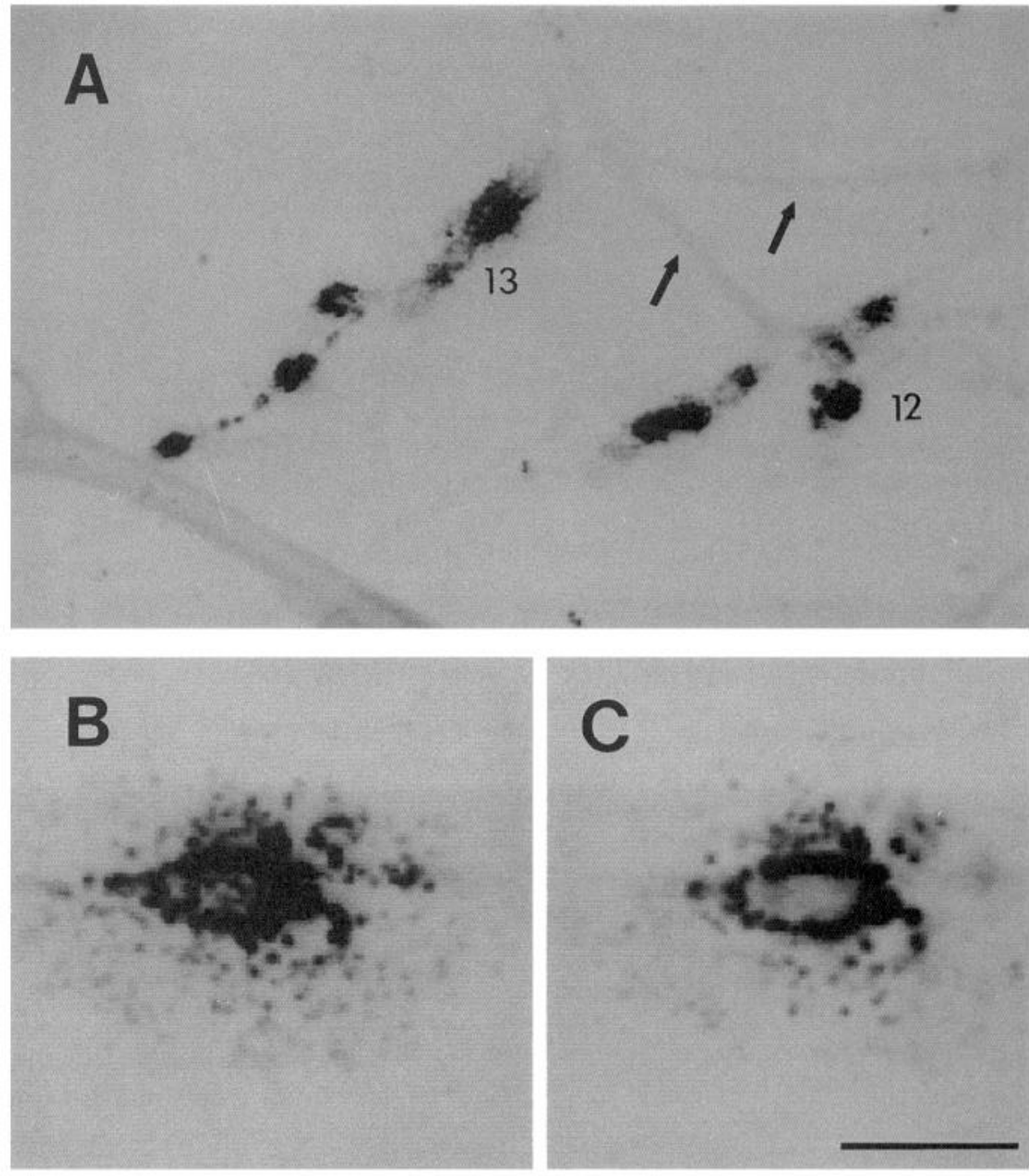

$\mathrm{ml}$ of buffer B (50 mm HEPES buffer, $\mathrm{pH} 7.6,150 \mathrm{~mm} \mathrm{NaCl}, 0.1 \%$ Triton X-100), and $200 \mathrm{ml}$ of buffer C (50 mM HEPES buffer, pH 7.6, $150 \mathrm{~mm} \mathrm{NaCl}, 10 \mathrm{~mm} \mathrm{MgSO}_{4}, 0.1 \%$ Triton X-100). After the application of the membrane fraction, the column was washed with $100 \mathrm{ml}$ of buffer $\mathrm{C}$ and eluted in twenty $0.5 \mathrm{ml}$ fractions with $0.5 \mathrm{M} \mathrm{N}$-acetyl-D-glucosamine, $5 \mathrm{~mm}$ EDTA in buffer $\mathrm{C}$. The peak of insulin binding appeared in fractions 9-12. Fractions containing insulin binding activity (denoted as "WGA extract") were combined and used for insulin binding assays. Protein content was determined by the Bio-Rad microassay method using BSA as a standard.

\section{Insulin binding assays}

Insulin binding experiments were carried out according to Cuatrecasas (1972). The total reaction volume was $150 \mu \mathrm{l}$ and contained $100 \mathrm{~mm}$ HEPES buffer, pH 7.9, $120 \mathrm{~mm} \mathrm{NaCl}, 0.1 \%$ Triton X-100, $2.5 \mathrm{~mm} \mathrm{KCl}$, $1.2 \mathrm{mM} \mathrm{MgCl}_{2}, 0.5 \mathrm{~mm}$ sodium acetate, and $1 \mathrm{~mm}$ EDTA (binding buffer), $0.7 \mathrm{nM}^{125} \mathrm{I}$-labeled $\mathrm{Tyr}^{\mathrm{A} 14}$-porcine insulin (receptor grade; specific activity, $2200 \mathrm{Ci} / \mathrm{mmol}$; New England Nuclear), and WGA extract (30 $\mu \mathrm{g}$ of protein). For competitive binding assays increasing concentrations of unlabeled porcine insulin (Sigma), human IGF I (Amhersham), or human IGF II (Sigma) diluted in $0.1 \%$ bovine serum albumin (Sigma) in PB were used. Samples were incubated at $22-24^{\circ} \mathrm{C}$ for $1 \mathrm{hr}$. This period was found to be sufficient to reach steady state conditions. Binding was stopped by adding $0.5 \mathrm{ml}$ of cold PBG $(0.1 \%$ bovine gamma globulin in PB) and $0.5 \mathrm{ml}$ of $25 \%$ polyethylene glycol (PEG; Sigma; MW 8000) in PB to precipitate the receptor. Samples were thoroughly mixed, incubated on ice for $10 \mathrm{~min}$, and then filtered on a Millipore manifold at $300 \mathrm{~mm} \mathrm{Hg}$ using $0.45 \mu \mathrm{m}$ Durapore filters (Millipore). Filters were washed two times with $3 \mathrm{ml}$ of $8 \%$ PEG in PB and radioactivity was measured in a Hewlett Packard gamma counter at $74 \%$ efficiency. Specific binding was determined by subtracting counts obtained from samples prepared as above but to which $10^{-5} \mathrm{M}$ unlabeled insulin was added. All measurements were performed in triplicate.

\section{Results}

Insulin receptor-like immunoreactivity at the body wall muscles

The body wall muscles of Drosophila larvae are composed of a regular array of 30 muscle fibers per hemisegment (Crossley, 1978). Each of these identifiable muscle fibers is contacted by one or more motorneurons in a stereotypic fashion that is characteristic for each muscle fiber (Johansen et al., 1989a). We examined the possibility that a dInsR might be localized at the body wall by using three approaches: dInsR-like immunocytochemistry, in vivo insulin-FITC binding, and phosphotyrosine immunocytochemistry. Phosphotyrosine immunocytochemistry was performed because in many species (including Drosophila) insulin and IGF I receptors are known to contain an intracellular tyrosine kinase domain (Petruzzelli et al., 1985b, 1986; Ullrich et al., 1985; Schlessinger and Ullrich, 1992). In addition, we examined the presence of a dInsR by receptor binding assays in whole larvae.

dInsR-like immunoreactivity was visualized using two monoclonal antibodies directed against the $\alpha$-subunit of the human placental InsR. Similar patterns of immunoreactivity were ob- 
served with both antibodies although the monoclonal from Chemicon gave higher levels of specific signal (comparative data not shown). dInsR-like immunoreactivity was observed at all neuromuscular junctions studied (segments 1-7; all the internal muscles, 1-8; and those external muscles not obstructed by overlying muscles, $12-17,20$; the superficial muscle layer was not closely examined; see Fig. 6), where it surrounded synaptic boutons near the nerve branching area (Fig. 1) of third instar larvae $(n=63)$. In order to see the specific location of the receptor on synaptic boutons or the postsynaptic muscle membrane, optical sectioning of synaptic boutons was performed near the branch point using confocal microscopy. As shown in Figure $1, B$ and $C$, immunoreactivity was restricted to the periphery of synaptic boutons in a punctate arrangement, but outside the synaptic boutons (Fig. 1). These observations are consistent with the receptor being localized on the postsynaptic muscle fiber. However, our method does not allow us to ascertain whether receptor was also present in the membrane of the presynaptic terminal. Electron microcopical examination will be required to address this issue.

Most of the boutons that were immunoreactive were type I, large varicosities. Smaller varicosities, probably of the intermediate type, also exhibited staining though usually with much less intensity and reliability. Only a proportion of the boutons were usually stained at any one muscle fiber. There was considerable variability from preparation to preparation in the intensity of immunoreactivity in the nerve branching area, although immunoreactivity was always present.

dInsR immunoreactivity was also apparent at other sites, particularly in the brain and ventral ganglion. Because the dInsR immunohistochemistry was performed in unpermeabilized preparations, it is unknown whether the observed pattern reflected the complete pattern of InsR-like immunoreactivity or, more likely, a small fraction of the total receptors that was accessible to the antibody. In addition to the CNS, InsR-like immunoreactivity was also observed around the periphery of a few cells in the imaginal disks and salivary gland cells (not shown).

In order to determine when dInsR was first expressed during larval development, a series of larvae was staged from egg-laying and observed at different stages of larval development by using anti-InsR immunocytochemistry. For these experiments, immunostaining was intensified by using a biotinylated secondary that was then reacted with FITC-conjugated avidin. Under these conditions, dInsR-like immunoreactivity was seen in the early second instar $(n=15)$, when it was concentrated around synaptic boutons (Fig. $2 A$ ). As in third instar larvae, the intensity of staining varied considerably from segment to segment and, because staining intensity was lower in general, immunoreactivity was not always noticable in every muscle. Three early first instar larvae, of 14 examined, had very limited staining at the branch point region of muscle 12 , but these samples had exceptionally high background staining. All other first instar body wall muscles were devoid of immunoreactivity at neuromuscular junctions (Fig. 2B).

\section{In vivo visualization of insulin binding}

Stronger evidence that the molecule detected by immunocytochemistry was an InsR came from studies of insulin binding in vivo. For this, third instar larval body wall preparations $(n=$ 67) were incubated in the presence of insulin (10-100 nM FITCconjugated insulin). In some cases samples were incubated with
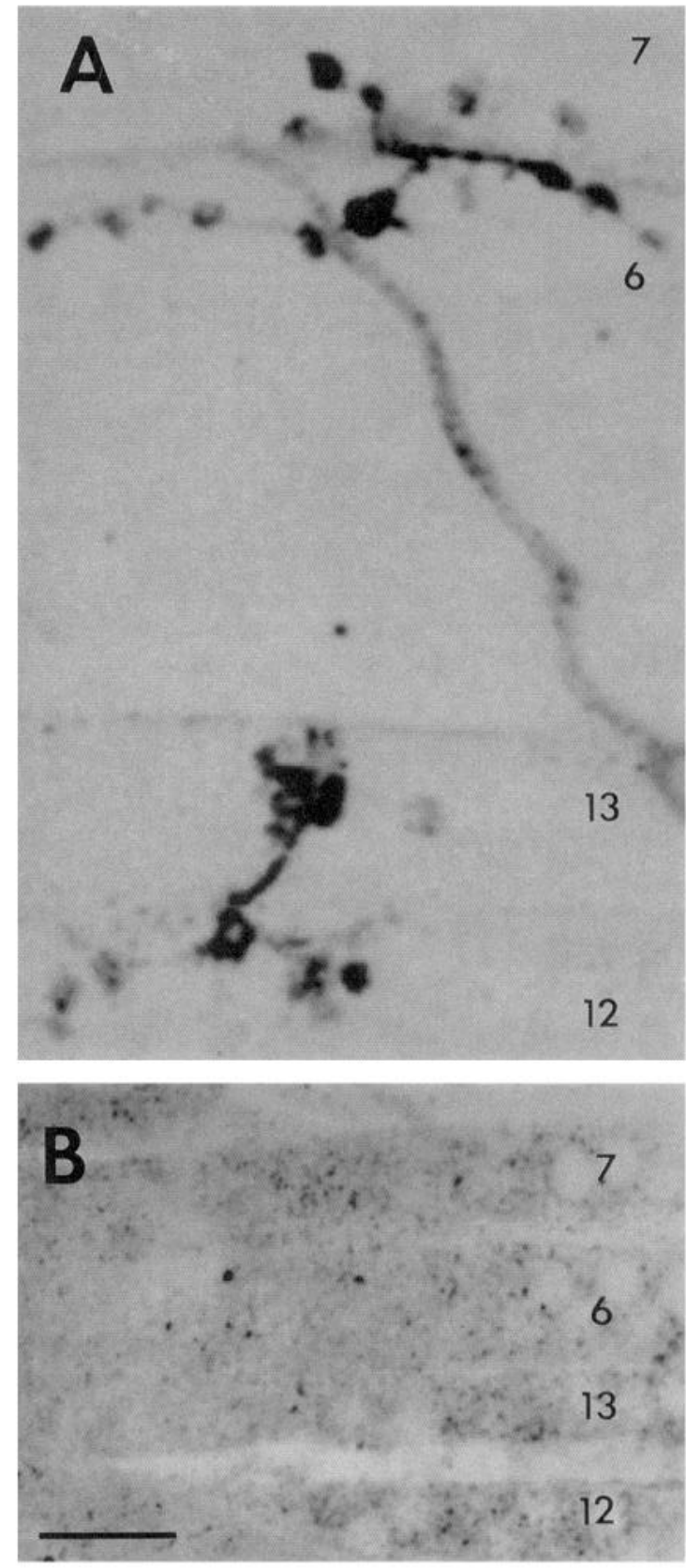

Figure 2. Developmental expression of dinsR-like immunoreactivity. $A$, Muscles $6,7,12$, and 13 in a late second instar larva. Note that at this stage, label is concentrated around synaptic boutons. $B$, Muscles 6 , $7,12,13$ in a first instar larva. No label was found around synaptic boutons. Scale bar: $5 \mu \mathrm{m}$ for $A, 12 \mu \mathrm{m}$ for $B$.

FITC-conjugated insulin and observed directly under epifluorescence. With this method fluorescence was observed at boutons localized around the nerve branch point areas. However, due to the peptide:FITC ratio (1:1), fluorescence was dim and quickly faded under UV illumination. Also, the live preparation would often move, making photographic documentation very difficult.

To circumvent these difficulties, samples were fixed after incubation with exogenous insulin-FITC and observed with the confocal microscope. As expected for receptor-bound insulin, this method revealed a pattern of staining (Fig. $3 A, C$ ) very much like that of dInsR-like staining. Label was concentrated at syn- 


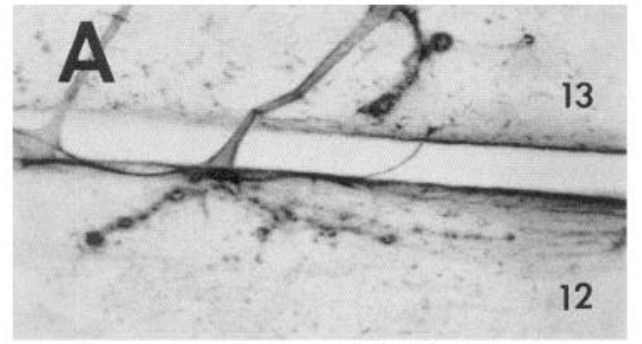

Figure 3. Confocal images of in vivo insulin-FITC binding $(A, C)$ and phosphotyrosine-like immunoreactivity $(B$, $D)$. $A$ and $B$, Neuromuscular junction at muscle 12 and 13. $C$ and $D$, High magnification view of a series of synaptic boutons. Note the resemblance of label to that obtained by dInsR-like immunocytochemistry (Fig. $1 B, C$ ). Anterior is to the left. Scale bar: $60 \mu \mathrm{m}$ for $A$ and $B ; 15 \mu \mathrm{m}$ for $C$ and $D$.

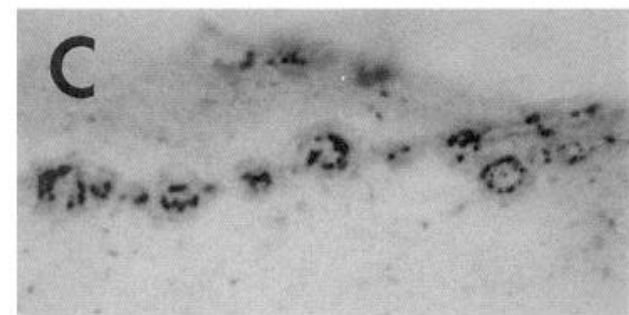

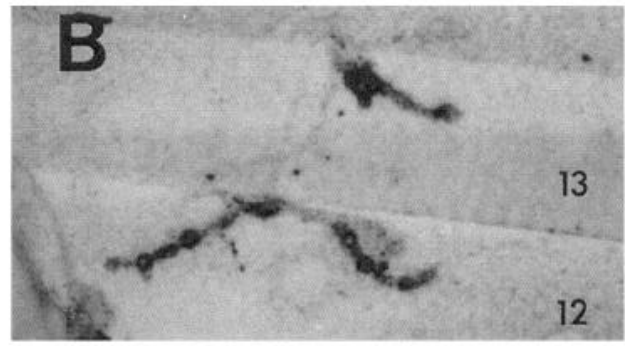

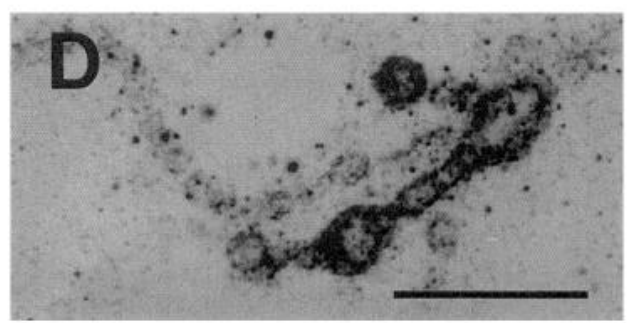

aptic boutons near the nerve branching area in a punctate pattern, and only some boutons were stained, primarily large ones (Fig. $3 A, C$ ). The staining was not as densely distributed around the boutons as it was for anti-dInsR immunoreactivity, but this may be due to binding of only newly available receptor sites. There was also light staining of optic disks, and the CNS appeared much as it did with dInsR immunoreactivity.

\section{Phosphotyrosine-like immunoreactivity at the body wall muscles}

InsRs as well as IGF receptors from several species have been shown to contain an intracellular tyrosine kinase domain (reviewed in Unger et al., 1991). Similarly, in Drosophila, Petruzzelli et al. $(1985 \mathrm{~b}, 1986)$ have shown the presence of a kinase domain in the fly receptor homolog that catalyzes insulin-de-



Figure 4. Insulin binding to WGA extract from Drosophila larval membranes; $30 \mu \mathrm{g}$ of extract was incubated in the presence of $0.7 \mathrm{nM}$ ${ }_{125} \mathrm{I}$-insulin and increasing concentrations of cold insulin (๑), IGF I (o), and IGF II ( $\square$ ). Data represent average \pm SEM of three independent experiments (each done in triplicate). pendent autophosphorylation of the receptor. If dInsR-like molecules are indeed localized at the body wall neuromuscular junction, dInsR-like immunoreactivity and in vivo insulin binding should be localized in a similar pattern as phosphorylated tyrosine residues. To examine this possibility we used a monoclonal antibody that selectively binds to phosphotyrosine residues. We found that the pattern of immunoreactivity at the body wall muscles of third instar larvae $(n=47)$, using this antibody, paralleled dInsR-like immunoreactivity and in vivo insulin binding (Fig. 3B,D). As with dInsR-like immunoreactivity and in vivo insulin-FITC binding, phosphotyrosine-like immunoreactivityy was localized around varicosities of the branch point area. Phosphotyrosine staining was also observed in other tissues, notably the clusters of photoreceptors in the eye disk and the CNS neuropil.

\section{InsR binding assays}

The results presented in the previous sections strongly suggest the presence of a dInsR at the body wall muscles of Drosophila larvae. Direct pharmacological demonstration of a larval dInsR is provided by in vitro receptor binding assays. However, the low concentration of InsR in larvae (see below) precluded this analysis in isolated body walls, and therefore we used whole larvae for this analysis. Although studies in whole larvae are not direct evidence for the presence of an InsR in the body wall muscles, our results demonstrate that an InsR is indeed present in larvae.

Specific binding of insulin to larval membranes was analyzed at steady state in a competitive binding assay. Detergent-solubilized receptors from larval membranes were partially purified by affinity chromatography on WGA-agarose (WGA extract). Thirty micrograms of WGA extract were incubated with $0.7 \mathrm{nM}$ ${ }^{125} \mathrm{I}-\mathrm{Tyr}^{\mathrm{A}}{ }^{14}$-insulin in the presence of increasing concentrations of unlabeled insulin, IGF I, or IGF II. As shown in Figure 4, competition of tracer-labeled insulin by cold insulin shows a mean half-maximal inhibition of binding $\left(\mathrm{ED}_{50}\right)$ of about $10 \mathrm{nM}$ whereas with IGF-II, $\mathrm{ED}_{50}$ was $250 \mathrm{nM}$. IGF I was ineffective in displacing ${ }^{125} \mathrm{I}$-insulin bound to the WGA extract in the concentration range tested $\left(2.5 \times 10^{-10}\right.$ to $\left.2.5 \times 10^{-7} \mathrm{M}\right)$. Scatchard analysis was performed using the program LIGAND (Munson and Robard, 1980). It was found that the dInsR in the WGA extract bound insulin with a $K_{D}$ of $13.8 \pm 4.2 \mathrm{~nm}$. About $800 \mu \mathrm{g}$ of 

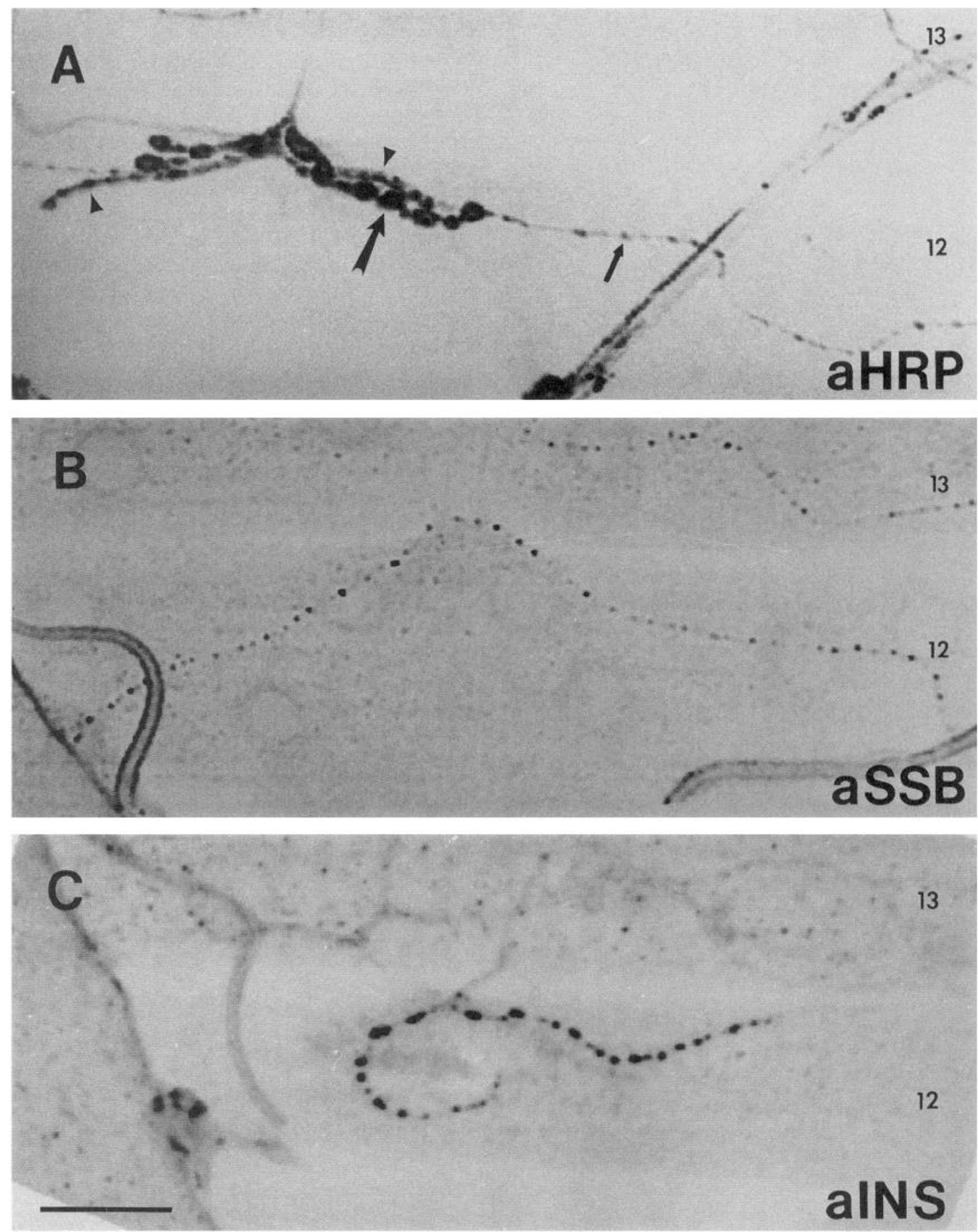

Figure 5. Morphologically and immunologically distinct synaptic terminals at body wall muscle 12 of third instar larvae visualized by anti-HRP $(A)$, anti-SSB $(B)$, and anti-insulin $(C)$ immunocytochemistry shown in different preparations. Samples were observed using confocal microscopy. In $A$, all synaptic terminal types are stained: type I, large arrow; type II, small arrow; anti-insulin, arrowheads. In $B$, only type II terminals are labeled. Note that insulin-immunoreactive terminals $(C)$ are distinct both in bouton size and/or length to type I and type II terminals. Anterior is to the left. Scale bar, $33 \mu \mathrm{m}$.

insulin-binding activity was recovered from the WGA affinity column. This corresponded to about $52 \pm 7 \mathrm{fmol}$ of insulinbinding activity per gram of larvae (about $52 \mathrm{amol} / \mathrm{larvae}$ ) or $2.6 \pm 0.35 \mathrm{fmol} / \mu \mathrm{g}$ of Triton-extracted membrane protein.

\section{Insulin-like immunoreactivity at the body wall muscles}

We next examined whether an insulin-like peptide was also expressed at the neuromuscular junction using three polyclonal antibodies directed against vertebrate insulin. The three gave identical patterns of immunoreactivity. Unlike dInsR, which was observed at the branching area of all muscle fibers examined in abdominal segments $1-7$, insulin-like immunoreactivity was predominantly found at muscle 12 in synaptic boutons at abdominal segments $2-5$ (92-100\% of 52 fibers scored for each segment; Figs. 5, 6). Segment 6 showed staining in one muscle 12 fiber of 52 analyzed. Segments 1 and 7 did not have any 


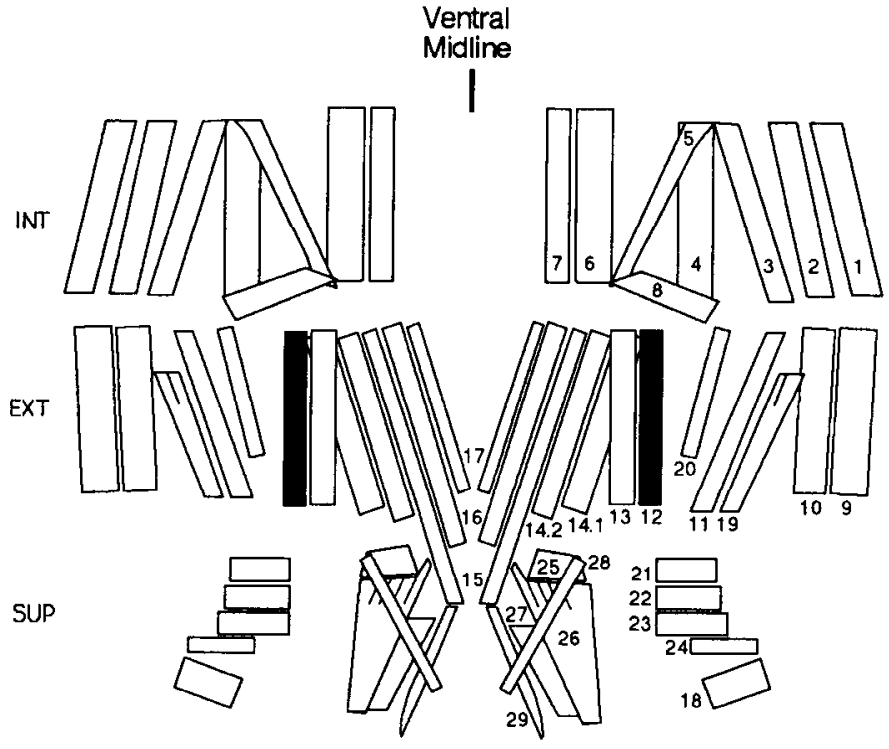

Figure 6. Diagrammatic representation of insulin-like immunoreactivity at muscle 12 (shown in black). The muscles shown are the fibers of a single abdominal segment that has been divided into three layers [internal $(I N T)$, external $(E X)$, and superior $(S U P)$ ] for clarity. Drawing modified from Anderson et al. (1988).

staining (20 and 24 hemisegments scored, respectively). Muscle 13 showed staining at segments $2-5$ in $6 \%$ of fibers (52 fibers scored/segment). Staining in muscles other than these occurred in only three fibers of 52 hemisegments analyzed.

Two types of terminals at muscle 12 have been previously described: short terminals containing large $(5-8 \mu \mathrm{m})$ synaptic boutons (type I) and long terminals containing small (1-2 $\mu \mathrm{m})$ boutons (type II) (Johansen et al., 1989a; Budnik et al., 1990; Budnik and Gorczyca, 1992). Insulin-like immunoreactivity defined a third kind of morphologically distinct terminal (type III). Figure $5 A$ shows muscle 12 stained with a nervous systemspecific antibody (anti-HRP) that stains all varicosity types (Johansen et al., 1989b; Budnik et al., 1990). In Figure $5 B$, muscle 12 from a different preparation is stained with anti-SSB antiserum. This antiserum was characterized in a previous study and was shown to label type II terminals selectively (Budnik and Gorczyca, 1992). The insulin-immunoreactive terminals in third instar larvae $(n=70)$ were of intermediate length and intermediate bouton size between type I and type II terminals (compare Fig. 5C with Fig. 5A,B; see also Jia et al., 1993), and the boutons were often elongate. Insulin-containing boutons typically paralleled SSB boutons for much of their length. As with the SSB antigen, insulin-like immunoreactivity was primarily in boutons as opposed to neurites. Occasionally staining could be detected in the nerve as it crossed over muscle 13 before branching at muscle 12 . Insulin-like immunoreactivity was completely abolished by preincubating the insulin antiserum in the presence of $2.5 \mu \mathrm{M}$ insulin. In contrast, preabsorption with human IGF I and II did not have noticeable effects on the levels of immunoreactivity (data not shown).

\section{Developmental expression of insulin-like immunoreactivity}

The developmental expression of insulin-like peptide was examined at different larval stages. Figure 7 shows the expression of insulin-like immunoreactivity at different larval stages. In Figure 8 the number of boutons expressing insulin-like peptide at different stages is quantified and compared to the number of boutons expressing HRP and SSB immunoreactivity. Insulinlike immunoreactivity first appeared during the late first to early second instar (15-25 hr after hatching). Muscle 12 of most first instar ( $n=14$ larvae) body wall muscles appeared completely devoid of insulin immunoreactivity. In two samples, a single immunoreactive varicosity could be found in one or two muscles of late first instar larvae (Figs. $7 A, B ; 8)$. In contrast, insulin-like immunoreactivity was consistently observed at muscle 12 (Figs. $7 C, 8)$ of second instar larvae $(n=19$ larvae). However, these immunoreactive terminals appeared less extensive (much shorter and with only a few varicositics) than those in the early or late third instar body wall (compare Figs. $7 C, D ; 8$ ). The staining observed in the segment boundaries (Fig. 7) was unspecific staining, made evident by its continued appearance in insulin preincubation experiments. The size of immunoreactive boutons increased with the age of the larvae (Fig. 7). As in the third instar, immunoreactivity was restricted to muscle 12 at all stages.

The increase in the number of boutons containing insulinlike peptide was accompanied by a similar increase of all types of boutons at muscle 12 and 13 at all stages examined (Fig. 8). This was clearly seen by labeling all boutons with the anti-HRP antibody, and type II boutons with the SSB antibody (Fig. 8). Our results show that all terminals innervating these muscles, including those containing insulin-like peptide, are in a process of active growth after synaptogenesis is established during the embryonic period (Johansen et al., 1989b), and throughout the larval stage.

\section{Insulin-like immunoreactivity in the CNS}

The CNS of the larva is composed of two brain lobes and a ventral ganglion that is formed by the fusion of the subesophageal, thoracic, and abdominal ganglia. Insulin-like immunoreactivity was found in several cell bodies in the brain and ventral ganglion, and along a longitudinal fiber (or fiber bundle) and varicosities in the lateral aspect of the CNS neuropil (Fig. 9). Figure $9 C$ is a diagrammatic representation of the third instar larval CNS showing the positions of cell bodies and neuropil that were consistently stained from preparation to preparation $(n=33)$.

Brain lobes. Between 8 and 10 immunoreactive cells were observed in the brain lobes (Fig. 9A). The most prominent of these were two nearly adjacent cells localized medially at the anterior region of the lobes. A large process was often seen extending medially from these. Two other prominent somata were located medially and posteriorly in the brain lobes (Fig. 9).

Ventral ganglion. Insulin-like immunoreactive neurons in the ventral ganglion can be classified into three types (Fig. 9). (1) Large lateral cells, with a medially oriented process, were positioned at each abdominal hemisegment near the point of emergence of the segmental nerves. (2) Smaller mediolateral cells were located dorsally at each abdominal hemisegment. These cells were observed as doublets in the first three abdominal hemisegments and as singlets in the more posterior segments. (3) A pair of medial neurons was found in what is thought to be the seventh abdominal segment (Fig. 9B,C). It was not unusual to find a few more cell bodies at various positions (especially at the thoracic region; see Fig. $9 \mathrm{~A}$ ) that did not fit into the above categories. However, their appearance was not consistent from preparation to preparation, and therefore they are not described in this report.

Neuropil. A prominent insulin-like immunoreactive longitudinal fiber (or bundle) was observed bilaterally at the lateral 

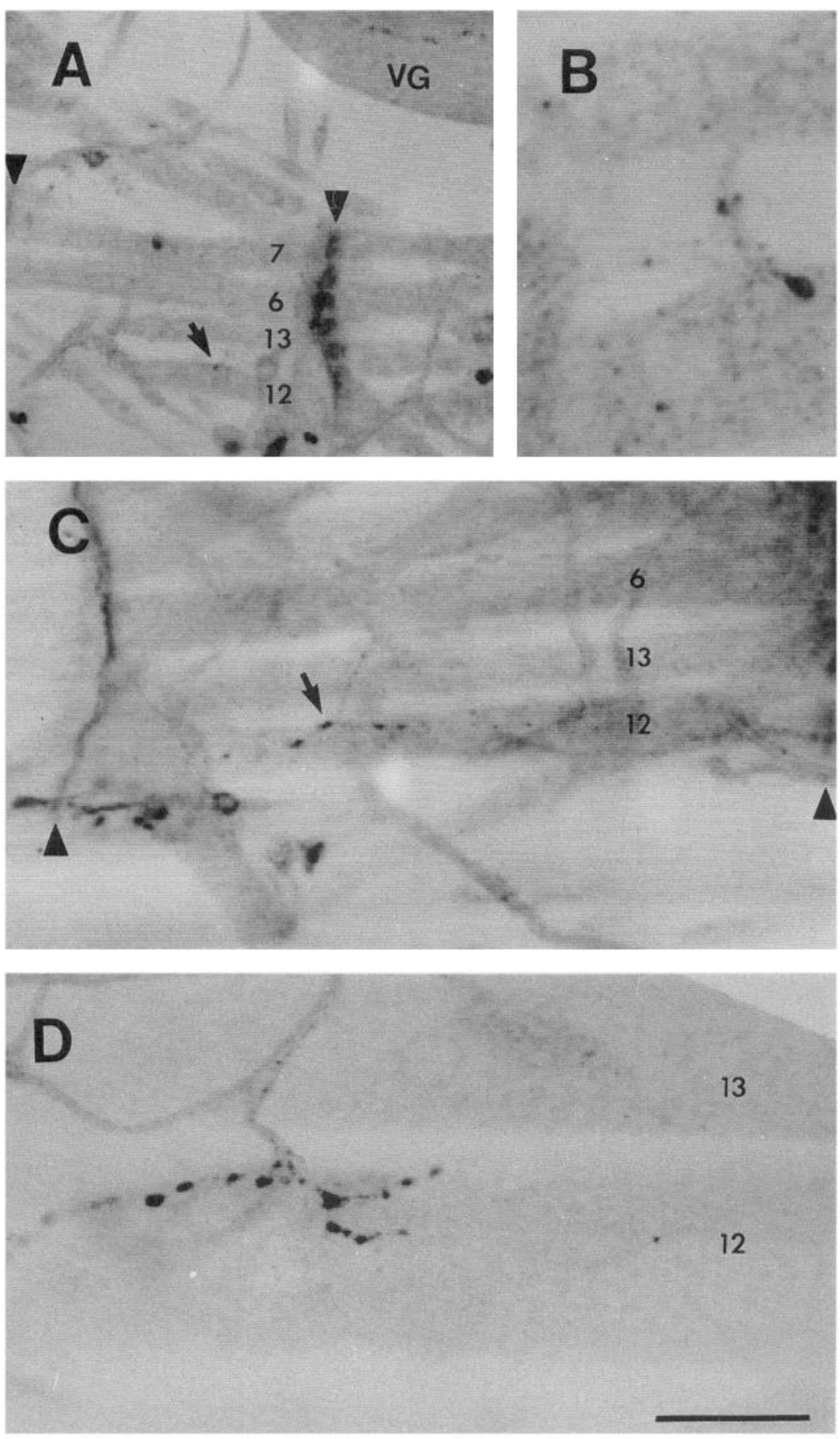

Figure 7. Developmental expression of insulin-like immunoreactivity at muscle 12. A, First instar body wall segment showing a single immunoreactive bouton at muscle 12 (arrow). This bouton is displayed at higher magnification in $B$. Most first instar body walls were devoid of insulin-like immunoreactivity (see text). $C$, Second instar body wall fiber exhibiting a more extensive immunoreactive branch at muscle $12(\mathrm{ar}$ row). $D$, Immunoreactivity at muscle 12 in a late third instar larva. Note the dramatic increase in muscle fiber size, synaptic bouton number and size, and terminal size from first to third instar. Arrowheads, segment boundaries. Dark staining at segment boundaries is unspecific. $V G$, ventral ganglion. Anterior is to the right in $A$, and to the left in $B$ $D$. Scale bar: $40 \mu \mathrm{m}$ for $A, C$, and $D ; 6$ $\mu \mathrm{m}$ for $B$. aspect of the neuropil (Fig. 9B,C). These fibers extended from the thoracic segments to about the seventh abdominal segment, where they joined at the midline. A more dorsal latticework of immunoreactive varicosities was observed running parallel and medially to this longitudinal fiber along most of its length (Fig. 9B).

\section{Discussion}

In this article, we examine whether an insulin-like peptide and a dInsR are expressed at the body wall neuromuscular junction of Drosophila larvae. The main incentive for this study was provided by the isolation of a dInsR mutant in which the pattern of innervation at the neuromuscular junction is altered (V. Budnik, R. Phillis, and M. Gorczyca, unpublished observations). We have provided evidence that both an insulin-like peptide and a dInsR are expressed at the body wall muscles.

\section{Expression of dInsR}

In this study we demonstrated the existence of a dInsR by a number of independent approaches: immunocytochemistry using two different monoclonal antibodies against the human receptor, in vivo binding of labeled insulin, phosphotyrosine immunocytochemistry, and in vitro binding assays. The first three 



Figure 8. Development of terminals containing insulin-like peptide in relation to the growth of other terminals at muscles 12 and $13 . A-C$, Drawings of ventral longitudinal muscles 12 and 13 in the third abdominal segment showing anti-HRP (top drawing), anti-SSB (middle drawing), and anti-insulin (bottom drawing) immunoreactivity at motor axon terminals. $A$, third instar; $B$, second instar; $C$, first instar. $D$, Number of HRP-, SSB-, and insulin-immunoreactive boutons at hatching $\left(n_{\mathrm{HRP}}=8, n_{\mathrm{SSB}}=8, n_{\mathrm{INS}}=6\right)$, mid first instar $\left(n_{\mathrm{HRP}}=12, n_{\mathrm{SSB}}=12, n_{\mathrm{INS}}=14\right)$, second instar $\left(n_{\mathrm{HRP}}=10, n_{\mathrm{SSB}}=10, n_{\mathrm{INS}}=8\right)$, early third instar $\left(n_{\mathrm{HRP}}=10, n_{\mathrm{SSB}}=10, n_{\mathrm{INS}}=8\right)$, and wandering third instar stages $\left(n_{\mathrm{HRP}}=29, n_{\mathrm{SSB}}=29\right.$, $\left.n_{\mathrm{INS}}=14\right)$, at muscles 13 (top histogram) and 12 (bottom histogram) of the third abdominal segment. Drawings of terminals were traced from confocal images. Numbers represent mean \pm SEM. 

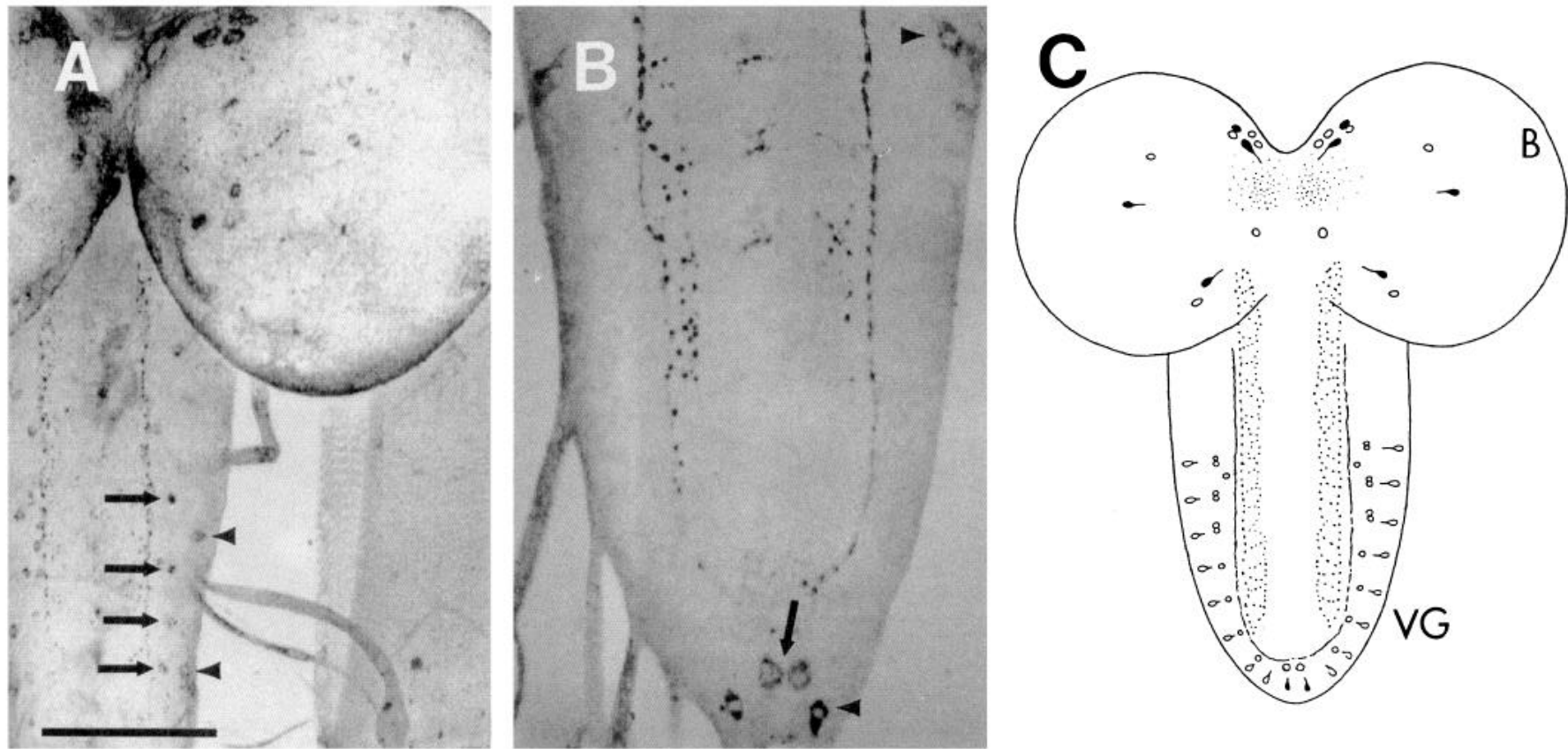

Figure 9. Insulin-like immunoreactivity in the larval CNS as visualized by confocal microscopy. $A$, Immunoreactivity in cell bodies and neuropil of the brain and ventral ganglion. Arrows, small mediolateral cells; arrowheads, large lateral cells. B, Immunoreactive neuropil and large terminal cells (arrows) of the ventral ganglion. $C$, Diagrammatic representation of insulin-like immunoreactivity in cell bodies and neuropil in the larval CNS. Solid cells represent greater immunoreactivity than hollow cells. Stippled areas correspond to areas in which immunoreactive neuropil was observed. $V G$, Ventral ganglion; up is anterior. Scale bar: $60 \mu \mathrm{m}$ for $A$, and $30 \mu \mathrm{m}$ for $B$.

methods indicated the presence of this receptor at the body wall neuromuscular junction. All three staining methods revealed a strikingly similar punctate arrangement of staining that was concentrated at nerve terminals. The strongest evidence for the presence of an InsR-like molecule at the body wall neuromuscular junction is the in vivo binding of insulin-FITC in the same pattern as that given by the antibodies above. Furthermore, the concentration at which in vivo binding of insulin-FITC was observed was very similar to the $K_{D}$ of dInsR detected by biochemical means. In vivo localization of InsRs has been observed before in fibroblasts (Schlessinger et al., 1978).

A similar pattern of staining was also found by using phosphotyrosine immunocytochemistry. Since a few other molecules are also phosphorylated on tyrosine residues, this observation by itself does not conclusively demonstrate the existence of an InsR. However, its similar localization to dInsR-like immunoreactivity, as well as to in vivo insulin binding, is consistent with this idea. The fact that dInsR can be labeled both by using antibodies against the human receptor and by in vivo bovine insulin binding indicates that this receptor has been highly conserved through evolution.

dInsR-like immunoreactivity, in vivo insulin binding, and phosphotyrosine-like immunoreactivity were localized at all body wall muscles studied. In particular, receptors were concentrated around synaptic boutons near the nerve branch point at each muscle fiber. Little or no immunoreactivity was observed in association with more distal regions of the synaptic terminals. A puzzling observation is the fact that whereas dInsRs were localized at every muscle fiber of the body wall, insulin-like immunoreactivity was only found on muscle 12 and from segment 2 to 5 . A possible explanation for this is that insulin, consistent with its putative role as a neurohormone, is released into the hemolymph by neurosecretory boutons at muscle 12 , where it diffuses to other target muscles. An alternative explanation is that insulin has multiple roles, acting globally as a neurohormonal factor, and more locally as a neurotransmitter or neuromodulator at muscle 12 .

The fact that InsR is localized around synaptic boutons suggests that the function of insulin is related to some interaction between the terminals and muscles. In vertebrates, IGF II has been related to neuromuscular junction formation and synapse elimination (Ishii, 1989; Caroni and Grandes, 1990). However, unlike Drosophila, IGF is expressed not at presynaptic terminals, but at the postsynaptic muscle (Ishii, 1989). Specific expression of InsRs or IGF receptors at the vertebrate neuromuscular junction has so far not been reported.

In addition to the body wall muscles, dInsR-like immunoreactivity was observed in the CNS and imaginal disks. Garofalo and Rosen (1988) have studied the tissue expression of Drosophila InsR homolog mRNA by in situ hybridization to tissue sections, using a cDNA clone corresponding to portions of the tyrosine kinase domain and the $3^{\prime}$ untranslated sequences. At all developmental stages studied, the highest level of expression was in the CNS. In third instar larvae, CNS staining was accompanied by staining in the imaginal disks, which is consistent with our results. There was no discussion of staining at the body wall muscles. One possible explanation for low staining in muscle is that the mRNA could be diffusely distributed throughout these very large multinucleate cells, but still produce enough protein to aggregate at the branch points. Receptor staining in embryos and adults awaits future examination.

\section{Receptor binding studies}

As further evidence for the existence of a dInsR in larvae, the presence of a glycoprotein membrane fraction with high-affinity binding to insulin was demonstrated. The very low concentra- 
tion of the dInsR (about 50 amol/larva) precluded its demonstration in isolated body wall muscles. Therefore, the receptor was demonstrated in whole larvae. The affinity of dInsR for insulin was similar to the one reported for Drosophila adults, and for the vertebrate placental receptor (Petruzzelli et al., 1985a). However, the concentration of receptor in larvae was about three times as much as the one reported for adult heads by Petruzzelli et al. (1985a). In vertebrates, the polypeptides IGF I and IGF II, which have high homology with insulin, have been described (see Gammeltoft, 1984). Both IGF I and IGF II can bind to the vertebrate InsR, but with less affinity. In this study we found that IGF II can also displace insulin in competitive binding assays. However, the $\mathrm{ED}_{50}$ is about 25 times larger than for insulin. IGF I, on the other hand, did not appear to bind to the rcceptor at the concentration range used.

\section{Expression of insulin-like immunoreactivity}

Insulin-like immunoreactivity at the body wall muscles (as detected with three different polyclonal antibodies) was exclusively localized to a subset of synaptic boutons on muscle 12 in abdominal segments $2-5$. We are aware that immunocytochemical methods alone are not enough to ascertain whether the antigen localized to boutons of muscle 12 was native insulin or another related peptide with a homologous antigenic determinant. However, the fact that three different polyclonal antibodies directed against vertebrate insulin show identical tissue expression, and that insulin, but not IGF I or II, completely abolished antibody binding, argues that the molecule stained is related to insulin. An insulin-like peptide, with similar activity to insulin and with the same molecular weight as insulin, has been isolated from Drosophila, but its amino acid scquencc is not known (Scccof and Dewhurst, 1974; Meneses and De los Angeles Ortiz, 1975; I e Roith et al., 1981). This peptide increased glucose oxidation and lipogenesis in mammalian adipocytes, and this activity was blocked by antibodies against mammalian insulin (Le Roith et al., 1981). The fact that a dInsR molecule is also localized at the neuromuscular junction and that high-affinity insulin-binding activity is found in Drosophila larvae makes it likely that the antibody used in this study detects a peptide closely related to insulin (see Holman, 1990, for a review on neuropeptides in insects).

A family of insulin-related peptides, including prothoracicotropic hormone, molluscan insulin-related peptides, and bombyxin, has been described in insects and mollusks (Nagasawa et al., 1984; Smit et al., 1988; Adachi et al., 1989; Gomot et al., 1992). In invertebrates insulin-like immunoreactivity has been shown to be associated with neural or neurosecretory structures (Hansen et al., 1990; Van Heumen and Roubos, 1990; Gomot et al., 1992). However, this is the first report in which insulin-like immunoreactivity is localized to the neuromuscular junction.

Five other neuropeptides - proctolin, FMRFamide, substance $\mathrm{P}$, cholecystokinin (CCK), and leukokinin $\mathrm{I}$-have been characterized in Drosophila, and shown to be expressed in the nervous system by immunocytochemical techniques (White et al., 1986; Anderson et al., 1988; Lundquist and Nässel, 1990; Nässel et al., 1990; Cantera and Nässel, 1992). Of these, proctolin and FMRFamide have also been identified by using biochemical techniques (Anderson et al., 1988; Nambu et al., 1988). In addition, the presence of a gene encoding the FMRF precursor has been identified in Drosophila (Nambu et al., 1988; Schneider and Taghert, 1988). One of these peptides, proctolin, is also expressed at the body wall neuromuscular junction, but its pattern of distribution is different from insulin (Anderson et al., 1988). The neuropeptides FMRFamide, substance $P$, and CCK are present in a few cell in the CNS and in a few peripheral targets, but are not expressed at the body wall muscles (White et al., 1986; V. Budnik, unpublished observations). Likewise, leucokinin I immunoreactivity is very specialized to a subset of synaptic boutons on muscle fiber 8 (Cantera and Nassel, 1992). Octopamine-like immunoreactivity has been reported at the terminals of body wall muscle 12 , but the subset of synaptic boutons it occupied was not discussed (Halpern et al., 1988). The expression of proctolin (Anderson et al., 1988), octopamine (Halpern et al., 1988), leukokinin I (Cantera and Nässel, 1992), and insulin-like peptide (this report) are examples of muscleand segment-specific specialization of axon terminals for the secretion of substances with putative transmitter/neuromodulator roles. Although the exact nature of this extreme specialization is at present unknown, it is possible that it represents a mechanism by which these substances are released into the body wall cavity, where they may have a hormonal role at other body wall muscles or organs within the body wall cavity.

Insulin-like immunoreactivity was also found in several cells in the brain and ventral ganglion. The morphology of immunoreactive cells in the CNS appeared neuronal in that many possessed axonal projections. The segmental distribution of cells in the ventral ganglion suggests that at least some of them may represent the motorneurons that provide innervation to muscle 12.

\section{Developmental expression of $d I n s R$ and insulin-like peptide}

Insulin-likc immunorcactivity was first obscrved in musclc 12 at the late first to early second instar stage. Initial expression appeared in a few synaptic boutons of muscle 12 and became increasingly more extensive in older larvae. This developmental expression is in contrast with the expression of glutamate, the excitatory transmitter at these neuromuscular junctions, and of an HRP-related antigen (Johansen et al., 1988b). Both glutamate and HRP immunoreactivities are expressed at embryonic stage 15-16, which is the period at which growth cones first contact the body wall muscles (Johansen et al., 1988b; Halpern et al., 1991; Sink and Whitington, 1991a,b). It is not known whether this late appearance of insulin-like immunoreactivity represents late gene expression, processing, or transport of the peptide to terminals that already existed or whether the terminals themselves grow and establish late synaptic connections with muscle 12. In this study we have found that all terminals at muscles 12 and 13 (defined by their staining with anti-HRP and antiSSB) undergo a dramatic process of growth during the larval period. This observation indicates that the expansion of terminals containing insulin-like peptide is likely to be the result of terminal growth and not a slow transport of the peptide down the axon to the boutons. However, further experiments such as dye filling motor neurons during embryonic and larval stages will be required to establish this with certainty.

As with insulin-like peptide, dInsR was expressed later in development (very early second instar), after most synaptic connections are established. The expression of dInsR coincided with the expression of insulin-like peptide. The late developmental expression of both insulin-like peptide and dInsR suggests that their actions are involved not in the process of early synaptogenesis, but rather in processes involved with neuromuscular junction maturation, such as junction expansion (see below). 
However, we must note that our methodology may simply not be sufficiently sensitive to detect low levels of staining in first instar larvae.

\section{Possible significance of the expression of insulin and InsR at the neuromuscular junction}

Although studies in both vertebrates and invertebrates have shown that insulin and InsR are localized in the nervous system, their potential role is obscure. An insight into their neurobiological function is suggested by in vitro experiments with neurons in culture. In these studies insulin promoted neurite elongation and neuronal survival (Seecof and Dewhurst, 1974; Recio-Pinto and Ishii, 1984; Recio-Pinto et al., 1986; Mudd et al., 1988; Kits et al., 1990; O’Dowd, 1990; Vanhems et al., 1990). Hence, it is possible that the same or similar actions occur in vivo. It is very interesting that InsRs belong to the tyrosine kinase class of receptors (reviewed in Ullrich, 1985; Unger, 1991), in view of the fact that tyrosine kinases have been implicated in axonal pathfinding. An example is in the Drosophila embryo, where the Abelson tyrosine kinase gene, through interactions with the genes fasciclin I and disabled, disrupts the normal axon outgrowth pattern of RP1, a motorneuron innervating muscle 13 (Maness et al., 1988; Gertler et al., 1989; Elkins et al., 1990).

Ishii (1989) has correlated IGF II gene expression with the phenomenon of polyinnervation and synapse elimination in rat neuromuscular junctions. In that study it was found that IGF II gene was expressed at high levels in muscles prior to and during synaptogenesis. During the period of synapse elimination and thereafter, IGF II mRNAs were downregulated. If the muscle was denervated, IGF II gene expression was upregulated in correlation with the capacity of the muscle to accept reinnervation. Consistent with these observations, Caroni and Grandes (1990) reported that exposure of rat or mouse muscle to low concentrations of IGF in vivo led to intramuscular nerve sprouting. We do not know whether an IGF II-like molecule is present in Drosophila, or whether a phenomenon similar to that described in rats also operates at Drosophila neuromuscular junctions. However, here we show that an insulin-like molecule is present at presynaptic terminals, not in the postsynaptic muscle fiber. In addition, the expression of dInsR and insulin-like peptide occurs well after synaptogenesis has started. The expression of an insulin-like molecule is followed by the expression of dInsR at restricted regions of muscles surrounding synaptic terminals. Therefore, it is likely that the function of these molecules in Drosophila is different from that described in rats.

In this study we have shown that in the Drosophila larval neuromuscular system, motorneuron process elongation occurs not only during embryogenesis (Johansen et al., 1989b; Sink and Whitington, 1991a,b), but also throughout the larval stages (also see Johansen et al., 1989b). As muscle fiber size increases, terminal arbors expand, presumably to match the growth of target muscles. The appearance of insulin-containing synaptic boutons by mid larval stages would be consistent with a role in the expansion of these terminals, which have already reached their targets. Genetic alterations of insulin-like peptide or dInsR number, structure, or distribution would allow one to probe their involvement in neural development. In this regard, we have recently isolated a dInsR mutant termed branch point disrupted (Budnik, Phillis, and Gorczyca, unpublished observations). This mutant maps to the same chromosomal location of the previously cloned dInsR (Petruzzelli et al., 1986), the receptor in the mutant has a decreased affinity for insulin, and some mutant alleles exhibit abnormal expression of the receptor and decreased phosphotyrosine-like immunoreactivity at the body wall muscles (Budnik, Phillis, and Gorczyca, unpublished observations). The alterations at the body wall muscles in this mutant include overgrowth of synaptic terminals to inappropriate muscle fibers, the presence of multiple branch points, and loose apposition of synaptic varicosities to the muscle. We hope that analysis of this mutant, as well as the discovery of mutations that alter insulin levels, will allow us to determine the signifcance of insulin and its receptor in the nervous system.

\section{References}

Adachi T, Takiya S, Suzuki Y, Iwami M, Kawakami A, Takahashi SY, Ishizaki H, Nagasawa H, Suzuki A (1989) cDNA structure and expression of bombyxin, an insulin-like brain secretory peptide of the silkmoth Bombyx mori. J Biol Chem 264:7681-7685.

Anderson MS, Halpern ME, Keshishian H (1988) Identification of the neuropeptide transmitter proctolin in Drosophila larvae: characterization of fiber-specific neuromuscular endings. J Neurosci 8:242255.

Basler K, Christen B, Hafen E (1991) Ligand-independent activation of the sevenless receptor tyrosine kinase changes the fate of cells in the developing Drosophila eye. Cell 64:1069-1081.

Brugge JS, Cotton PC, Queral AE, Barrett JN, Nonner D, Keane RW (1985) Neurons express high levels of a structurally modified activated form of pp60 c-src. Nature 316:554-557.

Budnik V, Gorczyca M (1992) SSB, an antigen that selectively labels morphologically distinct synaptic boutons at the Drosophila larval neuromuscular junction. J Neurobiol 23:1054-1066.

Budnik V, Wu C-F, White K (1989) Altered branching of serotonincontaining neurons in Drosophila mutants unable to synthesize serotonin and dopamine. J Neurosci 9:2866-2877.

Budnik V, Zhong Y, Wu C-F (1990) Morphological plasticity of motor axon terminals in Drosophila mutant with altered excitability. J Neurosci 10:3754-3768.

Campos-Ortega JA, Hartenstein V (1985) The embryonic development of Drosophila melanogaster. New York: Springer.

Cantera R, Nässel DR (1992) Segmental peptidergic innervation of abdominal targets in larval and adult dipteran insects revealed with an antiserum against leucokinin I. Cell Tissue Res 269:459-471.

Caroni P, Grandes P (1990) Nerve sprouting in innervated adult skeletal muscle induced by exposure to elevated levels of insulin-like growth factors. J Cell Biol 110:1307-1317.

Crossley CA (1978) The morphology and development of the Drosophila muscular system. In: The genetics and biology of Drosophila, Vol 2b (Ashburner M, Wright TRF, eds). New York: Academic.

Cuatrecasas $P$ (1972) Isolation of the insulin receptor of liver and fatcell membranes. Proc Natl Acad Sci USA 69:318-322.

Duve H, Thorpe A (1979) Immunofluorescent localization of insulinlike material in the median neurosecretory cells of the blowfly $\mathrm{Cal}$ liphora vomitoria. Cell Tissue Res 200:187-191.

Elkins T, Zinn K, Mc Allister L, Hoffmann M, Goodman C (1990) Genetic analysis of a Drosophila neural cell adhesion molecule: interaction of fasciclin I and Abelson tyrosine kinase mutations. Cell $60: 565-575$.

Fernandez-Almonacid R, Rosen OM (1987) Structure and ligand specificity of the Drosophila melanogaster insulin receptor. Mol Cell Biol 7:2718-2727.

Fults DW, Towle AC, Lauder JM, Maness PF (1985) pp60 ${ }^{\text {c-src }}$ in the developing cerebellum. Mol Cell Biol 5:27-32.

Gammeltoft S (1984) Insulin receptors: binding kinetics and structurefunction relationship of insulin. Physiol Rev 64:1321-1378.

Garofalo R, Rosen OM (1988) Tissue localization of Drosophila melanogaster insulin receptor transcripts during development. Mol Cell Biol 8:1638-1647.

Gertler FB, Bennett RL, Clark MJ, Hoffmann FM (1989) Drosophila $a b l$ tyrosine kinase in embryonic CNS axons: a role in axonogenesis is revealed through dosage-sensitive interactions with disabled. Cell 58:103-113.

Gomot A, Gomot L, Marchand C-R, Colard C, Bride J (1992) Immunocytochemical localization of insulin-related peptide(s) in the central nervous system of the snail Helix aspersa Müller: involvement in growth control. Cell Mol Neurobiol 12:21-32. 
Goodman CS, Grenningloh G, Bieber AJ (1992) Molecular genetics of neural cell adhesion molecules in Drosophila. In: The nerve growth cone (Letourneau PC, Kater SB, Macagno ER, eds), pp 283-303. New York: Raven.

Halpern ME, Anderson MS, Johansen J, Keshishian H (1988) Octopamine immunoreactive nerve terminals are found on a single identified muscle fiber of the Drosophila larval body wall. Soc Neurosei Abstr 14:383.

Halpern ME, Chiba A, Johansen J, Keshishian H (1991) Growth cone behavior underlying the development of stereotypic synaptic connections in Drosophila embryos. J Neurosci 11:3227-3238.

Hansen GN, Hansen BL, Jørgensen PN, Scharrer B (1990) Immunocytochemical localization and immunocytochemical characterization of an insulin-related peptide in the insect Leucophaea maderae. Cell Tissue Res 259:265-273.

Haydon PG, McCobb DP, Kater SB (1984) Serotonin selectively inhibits growth cone motility and synaptogenesis of specific identified neurons. Science 226:561-564.

Holman GM (1990) Insect neuropeptides. Ann Rev Entomol 35:201217.

Hubel DH, Wiesel TN, LeVay S (1977) Plasticity of ocular dominance columns in monkey striate cortex. Philos Trans R Soc Lond [Biol] 278:377-409.

Ishii DN (1989) Relationship of insulin-like growth factor II gene expression in muscle to synaptogenesis. Proc Natl Acad Sci USA 86: 2898-2902.

Jia X, Gorczyca M, Budnik V (1993) Ultrastructure of neuromuscular junctions in Drosophila: comparison of wild-type and mutants with increased excitability. J Neurobiol, in press.

Johansen J, Halpern ME, Johansen KM, Keshishian H (1989a) Stereotypic morphology of glutamatergic synapses on identified muscle cells of Drosophila larvae. J Neurosci 9:710-725.

Johansen J, Halpern ME, Keshishian H (1989b) Axonal guidance and the development of muscle fiber specific innervation in Drosophila cmbryos. J Neurosci 9:4318-4332.

Kater SB, Mills LR (1991) Regulation of growth cone behavior by calcium. J Neurosci 11:891-899.

Kits KS, de Vries NJ, Ebberink RHM (1990) Molluscan insulin-related neuropeptide promotes neurite outgrowth in dissociated neuronal cell cultures. Neurosci Lett 109:253-258.

Le Roith D, Lesniak MA, Roth J (1981) Insulin in insects and annelids. Diabetes 30:70-76.

Lundquist T, Nässel DR (1990) Substance P-, FMRFamide-, and gastrin/cholecystokinin-like immunoreactive neurons in the thoracoabdominal ganglia of the flies Drosophila and Calliphora. J Comp Neurol 294:161-178.

Maness PF, Aubry M, Shores CG, Frame L, Pfenninger KH (1988) $c$-src gene product in developing rat brain is enriched in nerve growth cone membranes. Proc Natl Acad Sci USA 85:5001-5005.

Meneses P, De los Angeles Ortíz M (1975) A protein from Drosophila melanogaster with insulin-like activity. Comp Biochem Physiol [A] 51:483-485.

Mudd LM, Master BA, Raizada MK (1988) Insulin and related growth factors: effects on the nervous system and mechanism for neurite growth and regeneration. Understanding brain development and repair of CNS injury. Neurochem Int 12:415-417.

Munson PI, Robard D (1980) LIGAND: a versatile computerized approach for characterization of ligand-binding systems. Anal Biochem 107:220-239.

Nagasawa H, Kataoka H, Isogai A, Tamura S, Suzuki A, Ishizaki H, Muzoguchi A, Fujiwara Y, Suzuki A (1984) Amino-terminal amino acid sequence of the sikworm prothoracicotropic hormone: homology with insulin. Science 226:1344-1345.

Nambu J, Murphy-Erdosh C, Andrews PC, Feistner GJ, Scheller RH (1988) Isolation and characterization of a Drosophila neuropeptide gene. Neuron 1:55-61.

Nässel DR, Lundquist T, Höög A, Grimelius L (1990) Substance P-like immunoreactive neurons in the nervous system of Drosophila. Brain Res 507:225-233.
Nishida Y, Hata M, Nishizuka Y, Rutter WJ, Ebina Y (1986) Cloning of a Drosophila cDNA encoding a polypeptide similar to the human insulin receptor precursor. Biochem Biophys Res Commun 141:474 481.

O'Dowd DK (1990) Effect of insulin on morphological and physiological differentiation of embryonic Drosophila neurons. Soc Neurosci Abstr 16:485.

Petruzzelli L, Herrera R, Garcia R, Rosen OM (1985a) The insulin receptor of Drosophila melanogaster. Cancer Cells 3:115-121.

Petruzzelli L, I Ierrera R, García-Arenas R, Rosen OM (1985b) Acquisition of insulin-dependent protein kinase activity during Drosophila embryogenesis. J Biol Chem 260:16072-16076.

Petruzzelli L, Herrera R, García-Arenas R, Fernandez R, Birnbaum MJ, Rosen OM (1986) Isolation of a Drosophila genomic sequence homologous to the kinase domain of the human insulin receptor and detection of the phosphorylated Drosophila receptor with an antipeptide antibody. Proc Natl Acad Sci USA 83:4710-4714.

Puro DG, Agardh E (1984) Insulin-mediated regulation of neuronal maturation. Science 225:1170-1172.

Recio-Pinto E, Ishii DN (1984) Effects of insulin, insulin-like growth factor II and nerve growth factor on neurite outgrowth in cultured human neuroblastoma cells. Brain Res 302:323-334.

Recio-Pinto E, Rechler MM, Ishii DN (1986) Effects of insulin, insulin-like growth factor-II, and nerve growth factor on neurite formation and survival in cultured sympathetic and sensory neurons. $J$ Neurosci 6:1211-1219.

Schlessinger J, Ullrich A (1992) Growth factor signaling by receptor tyrosine kinases. Neuron 9:383-391.

Schlessinger J, Shechter Y, Willingham MC, Pastan I (1978) Direct visualization of binding, aggregation, and internalization of insulin and epidermal growth factor on living fibroblastic cells. Proc Natl Acad Sci USA 75:2659-2663.

Schmidt JT, Tieman SB (1989) Activity, growth cones and the selectivity of visual connections. Comments Dev Neurobiol 1:11-28.

Schneider LE, Taghert $P$ (1988) Isolation and characterization of a Drosophila gene that encodes multiple neuropeptides related to $\mathrm{Phe}-$ Met-Arg-Phe- $\mathrm{NH}_{2}$ (FMRFamide). Proc Natl Acad Sci USA 85:19931997.

Seecof RL, Dewhurst S (1974) Insulin is a Drosophila hormone and acts to enhance the differentiation of embryonic Drosophila cells. Differentiation 3:63-70.

Sink H, Whitington PM (1991a) Location and connectivity of abdominal motorneurons in the embryo and larva of Drosophila melanogaster. J Neurobiol 22:298-311.

Sink H, Whitington PM (1991b) Pathfinding in the central nervous system and periphery by identified embryonic Drosophila motor axons. Development 112:307-316.

Smit AB, Vreugdenhil E, Ebberink RMH, Garaerts WPM, Klootwijk J, Joossee J (1988) Growth-controlling molluscan neurons produce the precursor of an insulin-related peptide. Nature 331:535-538.

Sorge LK, Levy BT, Maness PF (1984) pp60 $0^{- \text {src }}$ is developmentally regulated in the neural retina. Cell 36:249-257.

Ullirich A, Bell JR, Chen EY, Herrera R, Petruzzelli LM, Dull TJ, Gray A, Coussens L, Liao Y C, Tsubokawa M, Mason A, Seeburg PH, Grunfeld C, Rosen OM, Ramachandran J (1985) Human insulin receptor and its relationship to the tyrosine kinase family of oncogenes. Nature 313:756-761.

Unger JW, Livingston JN, Moss A (1991) Insulin receptors in the central nervous system: localization, signalling mechanisms and functional aspects. Prog Neurobiol 36:343-362.

Vanhems E, Delbos E, Girardie J (1990) Insulin and neuroparsin promote neurite outgrowth in cultured locust CNS. Eur J Neurosci 2:776-782.

Van Heumen WRA, Roubos EW (1990) Ultrastructural evidence for synthesis, storage and relcase of insulin-related peptides in the central nervous system of Lymnaea stagnalis. Neuroscience 39:493-500.

White K, Hurteau T, Punsal P (1986) Neuropeptide-FMRFamidelike immunoreactivity in Drosophila: development and distribution. J Comp Neurol 247:430-438. 